\title{
ANTIFEEDING AND INSECTICIDE PROPERTIES OF AQUEOUS AND ETHANOLIC FRUIT EXTRACTS FROM Melia azedarach L. ON THE ELM LEAF BEETLE Xanthogaleruca luteola Müller
}

\author{
Italo Chiffelle ${ }^{1}$, Amanda Huerta ${ }^{2 *}$, Fernando Azúa ${ }^{2}$, Karla Puga ${ }^{2}$, and Jaime E. Araya ${ }^{1}$
}

\begin{abstract}
Xanthogaleruca luteola Müller (Coleoptera: Chrysomelidae), a defoliator of Ulmus species currently present in several regions of central Chile, causes severe damage to trees, mainly in park areas, street tree-lines and gardens. The antifeeding and insecticidal activities of extracts from immature fruit of Melia azedarach L. (Meliaceae) were determined on adults of $X$. luteola in laboratory bioassays. Several concentrations of the extracts obtained with water and ethanol were used and their effectiveness and $\mathrm{LC}_{50}$ were determined. The antifeeding action of the water extracts caused $100 \%$ deterrence over concentrations of $3.6 \% \mathrm{w} / \mathrm{v}$. Both extracts were effective insecticides against adults, causing $86 \%$ mortality $(2.4 \% \mathrm{w} / \mathrm{v})$, with a better performance of the ethanol extracts, with a $\mathrm{LC}_{50}$ of $0.9 \% \mathrm{w} / \mathrm{v}$ on the $3^{\text {rd }}$ day after exposure, and $6.6 \% \mathrm{w} / \mathrm{v}$ on the $5^{\text {th }}$ day with the water extract.
\end{abstract}

Key words: Botanical insecticides, ethanol extract, water extract, Ulmus.

$\mathrm{E}$ lms (Ulmus spp.), ornamental trees originally from Europe, Asia, and America, grow in Chile mainly in parks and avenues in the central and south-central zones (Fu et al., 2003; Loewe and González, 2005). Elm trees in diverse communes of the Metropolitan (including Santiago and surrounding areas) and other regions are being attacked by the elm leaf beetle, Xanthogaleruca luteola Müller (Coleoptera: Chrysomelidae), a monophagous pest native to Europe that defoliates Ulmus spp., with preference for European species (Romanyk and Cadahia, 2002). It is considered the greatest defoliator of elms in plantations and ornamental trees in Europe, and has become the most important urban forestry pest in the USA, Argentina, Canada, and Australia (Lawson and Dahlsten, 2003). Its first recorded appearance in Chile occurred in April 1982, in Ritoque, a coastal resort North of Valparaíso (Askevold, 1991). Recently, this pest has been found in the Metropolitan area and the Libertador General Bernardo O`Higgins, Bío Bío, and La Araucanía Regions (SAG, 2010).

Damage by $X$. luteola begins with first-stage larvae,

${ }^{1}$ Universidad de Chile, Facultad de Ciencias Agronómicas, Casilla 1004, Santiago, Chile.

${ }^{2}$ Universidad de Chile, Facultad de Ciencias Forestales y Conservación de la Naturaleza, Casilla 9206, Santiago, Chile. *Corresponding author (ahuertaf@gmail.com).

Received: 7 October 2010.

Accepted: 17 January 2011. which consume the leaves starting at their underside epidermis, leaving the upper side untouched, which skeletonizes the laminae gradually during larval development. Later, when the adults emerge, a second period of foliar destruction ensues, when the adults feed on the leaves, leaving them with circular perforations. The two kinds of damage are often found together, indicating certain overlap between generations (Romanyk and Cadahia, 2002). The result may vary from partial to total defoliation, which reduces the aesthetic value of the tree, weakens it and makes it more susceptible to other pests, such as scolytid beetles transmitting Dutch elm disease (De Liñán, 1998). The level of damage is related to the number of generations per year. In regions where weather conditions are mild, the insect may complete up to three generations a season, as happens in Spain (Romanyk and Cadahia, 2002), and south-central California (Dreistadt et al., 2004).

Botanical insecticides have been used in agriculture for at least $2000 \mathrm{yr}$ in Asia and the Near East (Thacker, 2002). The interest in botanical compounds for pest control is based on their efficacy, degradability, and physiological activity (Rodríguez, 1998; Isman, 1999). The neem tree, Azadirachta indica L., and the Chinese neem, Melia azedarach L. (Meliaceae) are native to Asia and Australia and possess important insecticidal properties. Both species are used as ornamentals and have been naturalized in tropical and subtropical countries (Villalobos, 1996). 
Melia azedarach is native to Iran, India, and China (Hong and Ellis, 1998). In Chile it is commonly found on streets and avenues. The plant has become the object of studies to evaluate properties from different plant structures, in particular insecticide, antiviral, antioxidant, bactericide, and antiparasitic activities (Carpinella et al., 2003; Ahmed et al., 2008; Gende et al., 2008).

The insecticidal activity of $M$. azedarach is found on leaves, fruits, and seeds, and is due to a group of biologically active triterpenoids that have antifeeding effects (Valladares et al., 1997; Isman, 2006). Generally, extracts from green fruits and leaves have been those most efficacious because of their antifeeding effect, mainly on beetles and lepidopterans (Carpinella et al., 2003; Nathan and Kim, 2005; Defagó et al., 2006). However, $M$. azedarach has had a modest development as a commercial insecticide compared A. indica, due mainly to the content of meliatoxin in the fruit, a triterpenoid compound that is toxic to mammals (Schmutterer, 2002). In any event, the chemical composition of $M$. azedarach varies enormously from its wild form to the cultivated one. Trees in Argentina, for example, have fruit without meliatoxins, although they contain other triterpenoids, especially meliartenin, a strong insect antifeedant (Carpinella et al., 2003; 2005).

Considering the results of diverse studies of the insecticidal effectiveness of diverse parts of M.azedarach, and that in Chile this plant is grown as an urban tree may be used to prepare natural extracts for use against diverse pests, particularly $X$. luteola on elms.

The hypothesis of this study is that there are differences in the antifeeding and insecticidal properties of immature (green) fruit of M. azedarach when different solvents are used for extraction.

This research presents results of a study on the preparation of extracts using two solvents from immature fruit of $M$. azedarach, and the evaluation of their antifeeding effects on adult $X$. luteola in laboratory bioassays, to contribute to the integrated management of this insect pest or others defoliator insects.

\section{MATERIALS AND METHODS}

\section{Collecting $X$. luteola}

Last stage $X$. luteola larvae were manually collected from adult Ulmus minor Mill. trees in the Municipality of Maipú, Santiago, during the same period, and transported in cotton bags to the Forestry Entomology Laboratory, College of Forestry and Nature Conservation Sciences, Universidad de Chile, Santiago. They were set in Petri dishes lined with Whatman $\mathrm{N}^{\circ} 1$ filter paper and moistened with distilled water. The larvae were fed fresh elm tree leaves until developing into pupae. At this stage they were provided only with humidity and covered with more leaves. When the adults emerged, they were fed with fresh leaves and subsequently used in the bioassays.

\section{Collecting and preparation of fruit extracts}

Approximately $1 \mathrm{~kg}$ of bright green fruit from $M$. azedarach (20 fruits per tree) were obtained randomly from 32 adult trees growing as ornamentals, to avoid effects of any individual tree. The trees were located at the Antumapu Campus, Universidad de Chile (33 $34^{\prime}$ S; 70 $38^{\prime}$ W) in Santiago, Chile and the fruit were collected during the summer of 2008. Green fruit were selected because of their greater insecticide effectiveness (Chiffelle et al., 2009). The collected fruit were washed superficially with distilled water. Fruit extracts were prepared in the Chemistry Laboratory of the Departamento de Agroindustria y Enología, Facultad de Ciencias Agronómicas, Universidad de Chile, Santiago. First they were dried in a forced air stove (Memmert, Schwabach, Germany) at $45{ }^{\circ} \mathrm{C}$ until a constant weight $0.01 \mathrm{~g}$ sensitivity analytical scale (ELB3000, Shimadzu Scientific Instruments, Columbia, Maryland, USA). Fruit extracts were then ground with a grain mill (MC 0360, Ufesa, Spain) until obtaining a dust that was stored in sealed and dated glass vials. To prepare the extracts, the $M$. azedarach fruit dust was mixed with distilled water or 96\% pro-analysis ethanol (Merck, Darmstadt, Germany) in a solution at the highest possible concentration. The solutions were shaken $18 \mathrm{~h}$ in a magnetic stirrer(MR3001K, Heidolph, Kelheim, Germany), heating the first hour to 37 ${ }^{\circ} \mathrm{C}$. They were then filtered through a Whatman $\mathrm{N}^{\circ} 1$ filter paper and centrifuged in a centrifuge (HN-S Centrifuge, International Equipment Co., Philadelphia, USA) for 15 $\mathrm{min}$, after which the solutions were filtered again to obtain the stock solution. To determine the concentration of the base extracts, a fraction of the solutions were dried at 100 ${ }^{\circ} \mathrm{C}$ for $1 \mathrm{~h}$ in a forced air stove, and soluble solids were weighed on a $0.1 \mathrm{mg}$ sensitivity analytical scale (Boeco Equilab, Hamburg, Germany). Once the concentrations of these solutions were determined, the concentrations to be used in the treatments were prepared by dilution.

\section{Evaluation of the antifeeding action of $M$. azedarach}

The antifeeding effect of extracts on $X$. luteola adults was determined following the feeding choice test method in Defagó et al. (2006), with modifications. Six concentrations were evaluated for the ethanol extract $(1.0,1.8,2.4,3.0,3.6$ and $4.2 \% \mathrm{w} / \mathrm{v})$, and for the water extract $(2.4,3.0,3.6,4.2,6.0$, and $7.5 \% \mathrm{w} / \mathrm{v})$, with six replicates per treatment, using experimental units with three adults of $X$. luteola. Two elm tree leaves of the same size were selected per unit, and one leaf was coated on both sides with $500 \mu \mathrm{L}$ of the reported concentrations, and the other leaf was coated with $500 \mu \mathrm{L}$ of solvent 
(water or ethanol). The leaves were left to dry at room temperature. Each Petri dish (10 cm diameter) was set randomly with a treated leaf, another untreated, and three adult beetles. All the experiments were carried under a 18:6 photoperiod at $20{ }^{\circ} \mathrm{C}$ (Meiners and Hilker, 1997). The leaf area was measured initially and after 24 $\mathrm{h}$ using the Leaf Area Measurement Version 1.3 software (University of Sheffield, 2003). The ingested area was determined by the difference. The repellence percentage was calculated as (1-T/C) x 100, where $\mathrm{T}$ and $\mathrm{C}$ are the areas ingested of treated and control leaves, respectively (Schreck et al., 1977). Data were normalized by Bliss

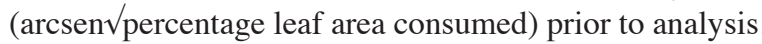
to stabilize variance error. Once the experimental part was completed, data from water extracts were studied with the Wilcoxon Signed-Rank Test using InfoStat statistical software (InfoStat, 2009).

\section{Evaluation of insecticide efficacy}

The bioassays were established with experiment units of three $X$. luteola adults with fresh elm tree leaves on moist filter paper in a clean 10-cm-diameter Petri dish. Concentrations of $3.9,6.8,7.3,8.6$ and $10.0 \% \mathrm{w} / \mathrm{v}$ were used for the water extracts, and $0.4,0.6,1.0,1.8$ and $2.4 \% \mathrm{w} / \mathrm{v}$ for the ethanol extracts. These concentrations were used to obtain mortality values from 25 through $75 \%$, adequate for Probit analysis (Robertson et al., 1984). The efficacy of fruit extracts was evaluated at the concentrations indicated plus the controls without any extract, with three replicates, all conducted simultaneously. The extracts were applied by immersing elm leaves for nearly $1 \mathrm{~min}$ in the corresponding solution. The beetles exposed afterwards were observed and the survivors were counted daily during the bioassay. All the experiments were carried out under the same environmental conditions described above. The percentages of daily and total mortality \pm standard error were obtained. Mortality values were corrected using Abbott's formula (Abbott, 1925) to eliminate natural mortality in the control (Silva et al., 2003). Data were adjusted to obtain the function with the best mathematical fit, as well as to obtain the $\mathrm{LC}_{50}$ by Probit analyses (Robertson et al., 1984) using Stadplus 5.4.0 software (AnalystSoft, 2008). Chi $^{2}$ tests were used to test the data fit to the Probit model.

Following the experimental component, data from the ethanol and water extracts were studied separately using a completely random ANOVA with five treatments for ethanol and five for water (five concentrations plus a control), with three replicates each. Data were normalized by Bliss (arcsen $\sqrt{ }$ percentage adult mortality) prior to analysis, to stabilize variance error. Significant differences among treatments were identified with Tukey tests ( $\mathrm{p} \leq$ 0.05), using InfoStat statistical software (InfoStat, 2009).

\section{RESULTS}

\section{Antifeeding effect}

The extracts obtained with the solvents had different antifeeding effects. The ethanol extract was not evaluated as an antifeedant because most of the insects died and those that survived did not feed on either the control or treated leaves. The water extract had a strong antifeeding effect at all evaluated concentrations, particularly at $3.6 \% \mathrm{w} / \mathrm{v}$ or higher, where inhibition reached $100 \%$ (Table 1).

\section{Insecticide efficacy of the aqueous extracts onto adults of $X$. luteola}

The survival of the insects fed with leaves treated with concentrations of the water extract were numerically lower that the control, starting day one, and these differences became statistically significant from day five (Figure 1a).

The $\mathrm{LC}_{50}$ of the water extract was $6.6 \% \mathrm{w} / \mathrm{v}\left(\mathrm{R}^{2}=\right.$ 0.87 ) on day 5 (Table 2). In general, the probit analysis provides good $\mathrm{LC}_{50}$ estimates when mortality obtained varies between 10 and $90 \%$. Beyond these limits, errors increase and affect calculations.

The maximum mortality $(76 \%)$ with the water extract was obtained when applying the highest concentration $(10.0 \% \mathrm{w} / \mathrm{v})$ (Figure 1a). The levels of mortality were lower with lower concentrations of the extract. However, the mortality levels were always significantly different from those with the control, indicating that mortality rates were due to the insecticidal extract.

\section{Insecticide efficacy of the ethanol extracts on $X$. luteola adults}

The survival rate of adults fed with leaves treated with the ethanol extract was lower than that of the control from day one, with significant differences between days 3 and 6 (Figure 1b). The most significant differences in

Table 1. Effect of water extracts from fruit of Melia azedarach on the feeding of Xanthogaleruca luteola adults on elm leaves in a random choice test.

\begin{tabular}{cccc}
\hline & \multicolumn{2}{c}{ Leaf area consumed } & \\
\cline { 2 - 3 } Extracts & $\begin{array}{c}\text { Untreated } \\
\text { control }\end{array}$ & $\begin{array}{c}\text { Treated } \\
\text { leaves }\end{array}$ & $\begin{array}{c}\text { Antifeeding } \\
\text { effect }\end{array}$ \\
\hline \% w/v & \multicolumn{4}{c}{$\%$} \\
2.4 & 1.1 & $0.1 *$ & 87.1 \\
3.0 & 3.1 & $0.1 *$ & 97.7 \\
3.6 & 3.3 & $0.0 *$ & 100.0 \\
4.2 & 2.9 & $0.0^{*}$ & 100.0 \\
6.0 & 2.5 & $0.0 *$ & 100.0 \\
7.5 & 2.2 & $0.0 *$ & 100.0 \\
\hline
\end{tabular}

*Significant differences between consumption on control and treated leaves (Wilcoxon signed-rank test, $\mathrm{P}<0.05$ ). 

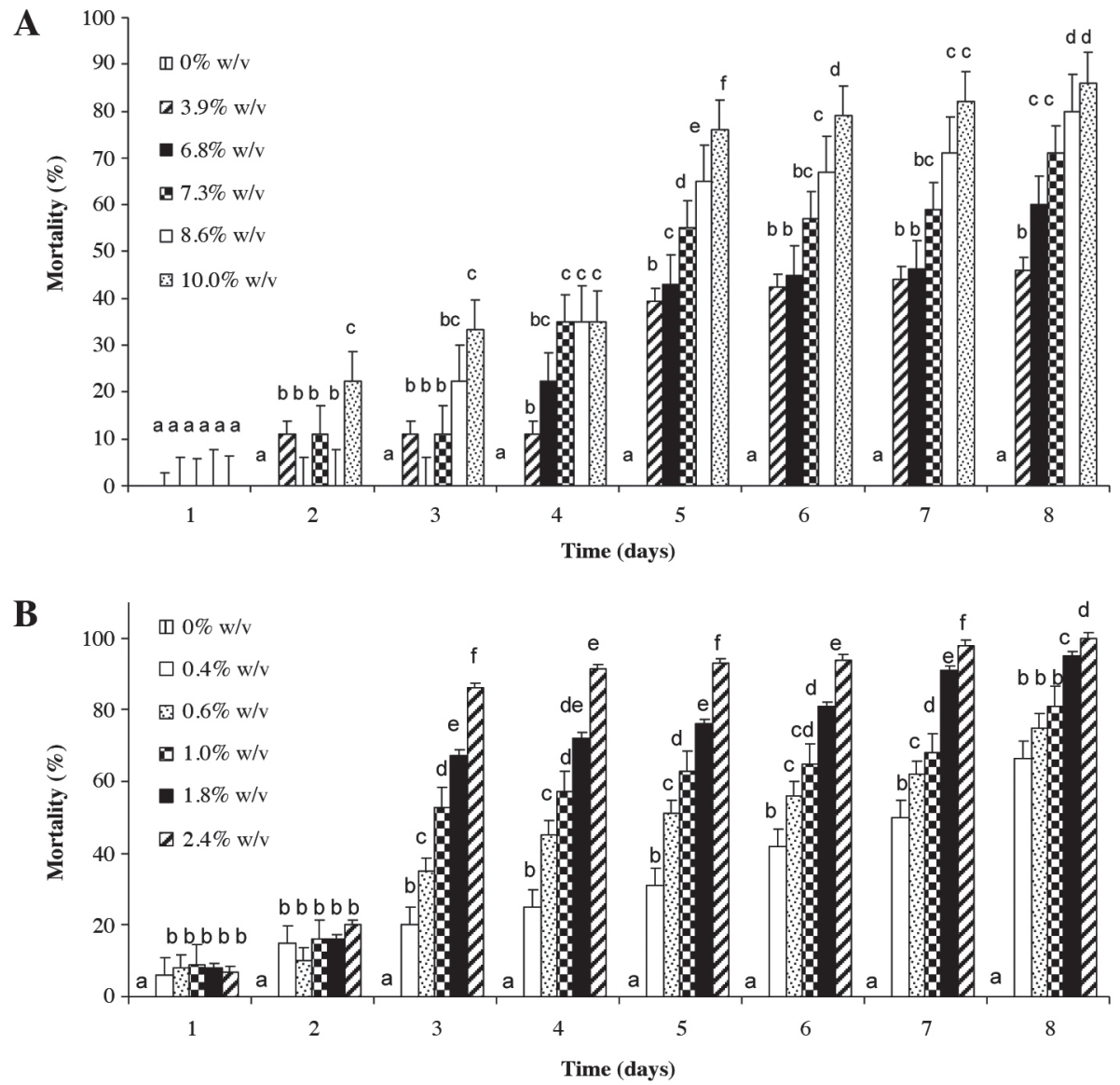

Different letters horizontally indicate significant differences among concentrations, according to Tukey tests $(\mathrm{p} \leq 0.05)$.

SE: standard error.

Figure 1. Average mortality $(\% \pm \mathrm{SE})$ of Xanthogaleruca luteola adults with leaf extracts from Melia azedarach at several concentrations at 1-8 d of evaluation. A) Water; B) ethanol.

mortality rates among concentrations occurred on day 3 . The values for the Probit fit for the calculation of the $\mathrm{LC}_{50}$ are presented in Table 2 . The $\mathrm{LC}_{50}$ of the ethanol extract was $0.9 \%\left(\mathrm{R}^{2}=0.91\right)$ on day 3 .

The highest mortality of $X$. luteola adults (86\%) with the ethanol extract $(2.4 \% \mathrm{w} / \mathrm{v})$ and the water extract
$(10.0 \% \mathrm{w} / \mathrm{v})$ were obtained with the highest concentrations (Figure 1). Smaller concentrations caused lower levels of mortality. All concentrations were statistically different from the control, with a clear trend toward increased mortality in response to higher concentrations of the extract.

Table 2. Mortality of Xanthogaleruca luteola adults after treating elm leaves with water and ethanol extracts from fruit of Melia azedarach.

\begin{tabular}{lcccccc}
\hline Extracts & Time & Slope & LC $_{\mathbf{1 0}}$ & LC $_{\mathbf{5 0}}$ & LC $_{\mathbf{9 0}}$ & Chi $^{\mathbf{2}^{*}}$ \\
\hline \multirow{3}{*}{ Water } & $\mathrm{d}$ & mean $\pm \mathrm{SE}$ & & & & \\
\multirow{2}{*}{ Ethanol } & 5 & $33.3 \pm 6.5$ & 2.0 & 6.6 & 21.7 & 2.79 \\
& 8 & $31.9 \pm 9.8$ & 0.9 & 3.1 & 11.1 & 1.38 \\
& 3 & $34.9 \pm 8.1$ & 0.3 & 0.9 & 3.0 & 2.07 \\
\hline
\end{tabular}

"Means below the $\mathrm{Chi}^{2}$ tabulated $(\mathrm{df}=5 ; \mathrm{p} \leq 0.05)=11.05$ indicate that the Probit model fits the experiment data for both extracts.

SE: standard error. 


\section{DISCUSSION}

The results in this study verified the antifeeding effect of the water extract from fruit of M. azedarach on $X$. luteola adults, with $100 \%$ inhibition at $3.6 \% \mathrm{w} / \mathrm{v}$, while the ethanol extracts were not evaluated as antifeedants because most of the insects died and the surviving ones did not feed on either the control or the treated leaves. Defagó et al. found antifeeding effects of $98 \%$ on X. luteola with $0.25 \%$ concentrations of an ethanol fraction and $100 \%$ effect with 1,2 , and $5 \%$ concentrations. The latter results are comparable to ours, since those authors used the same insect and fruit maturity stage, although we evaluated crude extracts, while they used Soxhlet extracted with $\mathrm{EtOH}$, which could explain the differences in results (Defagó et al., 2006). Other studies on the antifeeding effects of ethanol extracts of $M$. azedarach with other insects found close to $100 \%$ antifeeding effects with ethanol extracts from mature fruit at similar concentrations, 2, 5, and 10\%, applied to Spodoptera eridania Cramer (Lepidoptera: Noctuidae) (Rossetti et al., 2008), and other studies found that the ethanol extract at $10 \%$ from senescing leaves of $M$. azedarach had a total antifeeding effect (100\%) when applied to the coleopterans Diabrotica speciosa (Germar) (Chrysomelidae), Epilachna paenulata Germar (Coccinellidae), and Sitophilus oryzae (L.) (Curculionidae) (Valladares et al., 2003).

With respect to the toxicity of the ethanol solvent observed in our antifeeding activity bioassay, treatment of membranes with $2.5-12.5 \% \mathrm{w} / \mathrm{v}$ ethanol produced a slight stimulation of acetylcholinesterase activity in skeletal muscles and inhibition at higher concentrations (Cabezas-Herrera et al., 1992).

Other authors have studied the insecticidal effect of fruit extracts from M. azedarach. Applying water extracts from green fruits at $5 \%$ to the spider mite Tetranychus urticae Koch (Tetranychidae), Castiglioni et al. found 63\% mortality (2002). Other authors evaluated the insecticidal effect of these extracts on Bemisia tabaci Gennadius (Homoptera: Aleyrodidae) nymphs and found that at a 20\% concentration, mortality was slightly over $15 \%$, which increased to nearly $72 \%$ by adding a coadjuvant (Tween-20 detergent at 0.5\%) (Jazzar and Hammad, 2003).

Mortality levels $>70 \%$ were registered with Drosophila melanogaster Meigen (Diptera: Drosophilidae) adults by applying water extracts at a $1.07 \% \mathrm{w} / \mathrm{v}$ concentration (Huerta et al., 2008).

Levels of mortality in the literature indicate an insecticidal effect of water extract of fruits of $M$. azedarach on diverse insects, and coincide in part with the results obtained in our study, although at lower mortality rates than those registered by Huerta et al. (2008) with adults of D. melanogaster.

As per the Soxhlet extracted with ethanol from green fruits of M. azedarach, concentrations of 10 and $20 \%$ applied to Liriomyza huidobrensis Blanchard (Diptera: Agromyzidae) third instar larvae caused 55 and $65 \%$ mortality of pupae, respectively (Banchio et al., 2002). In the study by Defagó et al. (2006), the insecticide activity of mixed solvents (water, acetone, ethanol, and methanol) from green fruits was evaluated on adults of $X$. luteola, with average cumulative mortality levels of 91,100 , and $100 \%$ obtained for concentrations of 2, 5 , and $10 \%$, respectively. Similar levels of mortality were obtained in our study at the given concentrations. The results of Defagó et al. (2006) are important as they were obtained on the same insect, although with differences in the preparation of the extract, which they obtained via Soxhlet, while crude extracts were used in our work.

Other studies have evaluated the insecticidal effect of extracts obtained with other solvents, such as methanol, hexane, petroleum ether, and acetone, among others (Nunes et al., 2004). Ethanol extracts caused mortality effects in a shorter period of time, probably because of the greater solubility of the organic compounds in this solvent, which has a 25 absolute dielectric constant at $25{ }^{\circ} \mathrm{C}$ and lower polarity compared to the 79 level for water at the same temperature (Weast and Selby, 1966).

The $\mathrm{LC}_{50}$ obtained in our study differs from that in Huerta et al. (2008) for extracts from green fruit of M. azedarach, where concentrations of 2071 and 4382 ppm were obtained for ethanol and water, respectively. However, the application method in that research was different, where the extracts were mixed directly with the rearing substrate of $D$. melanogaster adults. In any event, in both studies, the effectiveness of the ethanol extracts was greater than that obtained with water.

Others authors have found a similar $\mathrm{LC}_{50}$ for the methanol bark extract from $M$. azedarach applied to larvae of two species of nocturnal lepidopterans, Trichoplusia ni Hübner (Noctuidae) and Pseudaletia unipuncta Haworth (Noctuidae). When the extract was applied on a foliar disc (feeding test), the $\mathrm{LC}_{50}$ for $T$. $n i$ and P. unipuncta were 6 and $3.1 \% \mathrm{w} / \mathrm{v}$. However, when the extract was sprayed directly on the body of $T . n i$ larvae, an $\mathrm{LC}_{50}$ of $12.6 \% \mathrm{w} / \mathrm{v}$ was found at day (Akhtar et al., 2008).

In X. luteola, Shekari et al. (2008) found that at $48 \mathrm{~h}$, the methanol extract from Artemisia annua (L.) (Asterales: Compositae) presented an $\mathrm{LC}_{50}$ of 43.8 and $15.4 \%$ when applied on third stage larvae and adults, 
respectively. This latter result is close to that found for the ethanol extract in our study.

\section{CONCLUSIONS}

The water extracts from green fruits of $M$. azedarach evaluated in laboratory bioassays had pronounced antifeeding effects on adults of $X$. luteola at all tested concentrations. The water ethanol extracts were more efficacious as bioinsecticides, causing $86 \%$ mortality at the highest concentration $(2.4 \% \mathrm{w} / \mathrm{v})$. The levels of mortality were lower with lower concentrations of the extract, although they were always significantly different from the control, indicating that mortality rates were due to the insecticidal extract. The lowest $\operatorname{LC}_{50}(0.9 \% \mathrm{w} / \mathrm{v})$ on adults of $X$. luteola was obtained with the ethanol extracts. The results obtained suggest an interesting opportunity for development of this bioinsecticide from green fruits of $M$. azedarach, for use in integrated pest management of $X$. luteola and possibly other pests.

\section{RESUMEN}

Propiedades antialimentaria e insecticida de extractos acuosos y etanólicos del fruto de Melia azedarach $\mathrm{L}$. en el escarabajo de la hoja del olmo Xanthogaleruca luteola Müller. Xanthogaleruca luteola Müller (Coleoptera: Chrysomelidae), un defoliador de especies de Ulmus presente en varias regiones de Chile central, causa daño severo en árboles principalmente en áreas de parques, árboles de calles, y jardines. Se determinó el efecto antialimentario e insecticida de extractos de frutos inmaduros de Melia azedarach L. (Meliaceae) sobre adultos de $X$. luteola en bioensayos de laboratorio. Se usaron varias concentraciones con agua y etanol de los extractos y se determinó su efectividad y su CL 50 . La acción antialimentaria de los extractos de agua causó un $100 \%$ de deterrencia sobre concentraciones de 3,6\% p/v. Ambos extractos fueron efectivos como insecticidas contra los adultos, causando un $86 \%$ de mortalidad $(2,4 \% \mathrm{p} / \mathrm{v})$, con un mejor comportamiento de los extractos con etanol con una $\mathrm{CL}_{50}$ de $0,9 \%$ p/v al tercer día después de la exposición, y $6,6 \% \mathrm{p} / \mathrm{v}$ al quinto día con los extractos acuosos.

Palabras clave: Insecticidas botánicos, extracto de etanol, extracto de agua, Ulmus.

\section{LITERATURE CITED}

Abbott, W.A. 1925. A method for computing the effectiveness of an insecticide. Journal of Economic Entomology 18:265-267.

Ahmed, M., M. Ahmed, H. Thayyil, K. Zameeruddin, and M. Ibrahim. 2008. Antioxidative activity of Melia azedarach Linn leaf extract. Iranian Journal of Pharmacology \& Therapeutics 7:31-34.

Akhtar, Y., Y. Yeoung, and M. Isman. 2008. Comparative bioactivity of selected extracts from Meliaceae and some commercial botanical insecticides against two noctuid caterpillars, Trichoplusia ni and Pseudaletia unipuncta. Phytochemistry Reviews 7:77-88.

AnalystSoft. 2008. Programa StatPlus version 5.4.0. Available at http://www.analystsoft.com/en/products/ statplus/download.phtml (accessed May 2009).

Askevold, I. 1991. On some poorly known, missidentified and mislabelled Chilean Chryso-melidae (Coleoptera). Revista Chilena de Entomología 19:11-15.

Banchio, E., G. Valladares, M. Defagó, S. Palacios, and C. Carpinella. 2002. Effects of Melia azedarach (Meliaceae) fruit extracts on the leafminer Liriomyza huidobrensis (Diptera, Agromyzidae): Assessment in laboratory and field experiments. Annals of Applied Biology 143:187-193.

Cabezas-Herrera, J., F.J. Campoy, and C. Vidal. 1992. Differential effects of ethanol on membrane-bound and soluble acetylcholinesterase from sarcoplasmic reticullum membranes. Neurochemical Research 17:717-722.

Carpinella, C., T. Defagó, G. Valladares, and M. Palacios. 2003. Antifeedant and insecticide properties of a limonoid from Melia azedarach (Meliaceae) with potencial use for pest management. Journal of Agriculture and Food Chemistry 51:369-374.

Carpinella, C., C. Ferrayoli, and M. Palacios. 2005. Antifungal synergistic effect of scopoletin, a hydroxycoumarin isolated from Melia azedarach $\mathrm{L}$. fruits. Journal of Agriculture and Food Chemistry 53:2922-2927.

Castiglioni, E., J. Vendramin, y M. Tamai. 2002. Evaluación del efecto tóxico de extractos acuosos y derivados de meliáceas sobre Tetranychus urticae (Koch) (Acari: Tetranychidae). Agrociencia 6:75-82.

Chiffelle, I., A. Huerta, and D. Lizana. 2009. Physical and chemicals characterization of Melia azedarach $\mathrm{L}$. fruit and leaf for use as botanical insecticide. Chilean Journal of Agricultural Research 69:38-45.

De Liñán, C. 1998. Entomología agroforestal. Insectos y ácaros que dañan montes, cultivos y jardines. 1309 p. Ed. Agrotécnicas S.L., Madrid, España. 
Defagó, M., G. Valladares, E. Banchio, C. Carpinella, and S. Palacios. 2006. Insecticide and antifeedant activity of different plant parts of Melia azedarach on Xanthogaleruca luteola. Fitoterapia 77:500-505.

Dreistadt, S., J. Clark, and M. Flint. 2004. Pests of landscape trees and shrubs: An integrated pest management guide. $2^{\text {nd }}$ ed. 501 p. University of California, Division of Agriculture and Natural Resources, Oakland, California, USA.

Fu, L., Y. Xin, and A. Whittemore. 2003. Ulmaceae. Flora of China 5:1-10.

Gende, L., J. Principal, M. Maggi, S. Palacios, R. Fritz, y M. Eguaras. 2008. Extracto de Melia azedarach y aceites esenciales de Cinnamomum zeylanicum, Mentha piperita y Lavandula officinalis como control de Paenibacillus larvae. Zootecnia Tropical 26:151156.

Hong, T., and R. Ellis. 1998. Contrasting seed storage behaviour among different species of Meliaceae. Seed Science and Technology 26:77-95.

Huerta, A., I. Chiffelle, y D. Lizana. 2008. Actividad insecticida de extractos del fruto de Melia azedarach en distintos estados de madurez sobre Drosophila melanogaster. Boletín de Sanidad Vegetal. Plagas 34:425-432.

InfoStat. 2009. InfoStat version 2009. Grupo InfoStat, FCA. Universidad Nacional de Córdoba, Córdoba, Argentina.

Isman, M.B. 1999. Pesticides based on plant essential oils. Pesticide Outlook 10:68-72.

Isman, M.B. 2006. Botanical insecticides, deterrents, and repellents in modern agriculture and an increasingly regulated world. Annual Review of Entomology 51:45-66.

Jazzar, C., and E. Hammad. 2003. The efficacy of enhanced aqueous extracts of Melia azedarach leaves and fruits integrated with the Camptotylus reuteri releases against the sweetpotato whitefly nymphs. Bulletin of Insectology 56:269-275.

Lawson, A., and D. Dahlsten. 2003. Implementation of a citywide monitoring program to base treatment decisions on elm leaf beetle abundance. Journal of Arboriculture 29:34-41.

Loewe, V., y M. González. 2005. El olmo: Una especie todo terreno. Revista Chile Forestal 317:46-48.

Meiners, T., and M. Hilker. 1997. Host locations in Oomyzus gallerucae (Hymenoptera: Eulophidae), an egg parasitoid of the elm leaf beetle Xanthogaleruca luteola (Coleoptera: Chrysomelidae). Oecologia 112:87-93.
Nathan, S., and S. Kim. 2005. Effects of Melia azedarach L. extract on the teak defoliator Hyblaea puera Cramer (Lepidoptera: Hyblaeidae). Crop Protection 25:287-291.

Nunes, E., R. Pires, e L. Fiuza. 2004. Efeitos, aplicações e limitações de extratos de plantas insecticidas. Acta Biológica Leopoldensia 26:173-185.

Robertson, J., K. Smith, N. Savin, and R. Lavigne. 1984. Effects of dose selection and sample size on the precision of lethal dose estimates in dose-mortality regression. Journal of Economic Entomology 77:833837.

Rodríguez, H. 1998. Determinación de toxicidad y bioactividad de cuatro insecticidas orgánicos recomendados para el control de plagas en cultivos hortícolas. Revista Latinoamericana de Agricultura y Nutrición (RELAN) 1:32-41.

Romanyk, M., y D. Cadahia. 2002. Plagas de insectos en las masas forestales. 338 p. Ediciones Mundi-Prensa, Madrid, España.

Rossetti, M., M. Defagó, M. Carpinella, S. Palacios, y G. Valladares. 2008. Actividad biológica de extractos de Melia azedarach sobre larvas de Spodoptera eridania (Lepidoptera: Noctuidae). Revista de la Sociedad Entomológica Argentina 67:115-125.

Schmutterer, H. (ed.) 2002. The neem tree. 892 p. Neem Foundation, Mumbai, India.

Schreck, C.E., K. Posey, and D. Smith. 1977. Protection time and minimum effective dosage against Aedes aegypti mosquitoes. USDA/ARS Technical Bulletin $1549.215 \mathrm{p}$.

SAG. 2010. Informativo fitosanitario forestal $\mathrm{N}^{\circ} 4$. Informativo del Subdepartamento de Vigilancia y Control Oficial Forestal, División Protección Agrícola y Forestal, Servicio Agrícola y Ganadero (SAG), Santiago, Chile.

Shekari, M., J. Sendi, K. Etebari, A. Zibaee, and A. Shadparvar. 2008. Effects of Artemisia annua L. (Asteracea) on nutritional physiology and enzyme activities of elm leaf beetle, Xanthogaleruca luteola Mull. (Coleoptera: Chrysomellidae). Pesticide Biochemistry and Physiology 91:66-74.

Silva, G., J. Rodríguez, y D. Pizarro. 2003. Evaluación de insecticidas en laboratorio. In Silva, G.Y., and R. Hepp (eds.) Bases para el manejo racional de insecticidas. 310 p. Universidad de Concepción, Facultad de Agronomía, Chillán, Chile.

Thacker, J.R.M. 2002. An introduction to arthropod pest control. 26 p. Cambridge University Press, Cambridge, UK. 
University of Sheffield. 2003. Program leaf area measurement. Available at http://www.shef. ac.uk/ nuoccpe/ucpe/leafarea.html (accessed October 2008).

Valladares, G., M.T. Defagó, S.M. Palacios, and M.C. Carpinella. 1997. Laboratory evaluation of Melia azedarach (Meliaceae) extracts against the elm leaf beetle (Coleoptera: Chrysomelidae). Journal of Economic Entomology 90:747-750.

Valladares, G., L. Garbin, M.T. Defagó, C. Carpinella, y S. Palacios. 2003. Actividad antialimentaria e insecticida de un extracto de hojas senescentes de Melia azedarach (Meliaceae). Revista de la Sociedad Entomológica Argentina 62(1-2):53-61.
Villalobos, P. 1996. Plaguicidas naturales de origen vegetal: Estado actual de la investigación. 35 p. Instituto Nacional de Investigación y Tecnología Agraria y Alimentaria, Madrid, España.

Weast, R., and S. Selby. 1966. Handbook of chemistry and physics: a ready reference book of chemical and physical data. $47^{\text {th }}$ ed. CRS Publications, Cleveland, Ohio, USA. 